\title{
Characterization and Evaluation of Dust on Building Construction Sites in Brazil
}

\author{
Emilia R. Kohlman-Rabbani ${ }^{1}$, Aviad Shapira ${ }^{2, *}$, Ana Rosa B. Martins ${ }^{1}$ and Béda Barkokébas Jr. ${ }^{1}$ \\ ${ }^{I}$ Polytechnic School of the University of Pernambuco, Recife, Brazil; ${ }^{2}$ Technion-Israel Institute of Technology, Haifa, \\ Israel
}

\begin{abstract}
Airborne dust can be hazardous to workers' health, especially when polymorphic crystalline forms of silica are present, which, depending on their concentration, specificity, and exposure time, can cause respiratory illnesses. In the majority of cases, the presence of some types of dust on building construction sites can be verified visually or through their effects, such as allergic reactions in workers and residents who live nearby. Construction workers are exposed to many raw materials and production processes that produce diverse types of dust, which propagate through the work environment and the neighborhood surrounding the construction site. The objective of this study was to quantitatively assess the exposure to dust of construction workers in Brazil, a country considered to be representative of the developing world and emerging economies. A preliminary study, conducted at several building sites to identify hazards, consisted of a survey of dust-generating construction materials, processes, and equipment. Nine activities that expose workers to dust were identified, of which six were chosen for further analytical study: mortar/concrete mixing, worksite cleaning, tile cutting, plastering, woodcutting, and wall/ceiling surface sanding for paintwork. The first three activities were analyzed for the presence of free crystalline silica in the total and respirable fractions; of these, the tile-cutting activity presented the highest exposure to silica concentration. Of the other three activities, paintwork and woodcutting exhibited total dust exposures equaling $368 \%$ and $159 \%$ of the international recommended limits, respectively. This study presents relevant information to help fight dust exposure on building construction sites and support the need to conduct quantitative dust analyses for workers in this sector in order to determine effective protection measurements.
\end{abstract}

Keywords: Brazil, construction sites, crystalline silica, occupational safety, respirable dust, total dust.

\section{INTRODUCTION}

The construction industry is of great importance in Brazil's socio-economic context since it encompasses a large number of firms that generate millions of direct, indirect, and induced jobs. The level of occupational safety and health in the country is, however, far below comfortable levels with regard to work-related accidents and adverse conditions in the work environment in this sector. The national statistical yearbook of the Brazilian social security institute provides information regarding work-related accidents. Of a total of 701,500 work-related accidents reported in 2010 , nearly $8 \%$ occurred in the construction industry [1]; while only $21 \%$ of these were without official notification, the prevalence of unreported cases is believed to be much higher. Note that underreporting of occupational accidents and illnesses in the construction industry is not unique to Brazil but rather is a well-known phenomenon throughout the world [2-4]. The severity and implications of this situation are even greater in the building construction sector, which is the focus of the current study: of the 54,664 cases reported in 2010 for the entire Brazilian construction industry, $36 \%$ were in the building sector, the highest rate among all construction sectors (e.g., infrastructure, demolitions).

The present study arose from a need for specific quantitative information regarding dust exposure in developing

*Address correspondence to this author at the Faculty of Civil and Environmental Engineering, Technion-Israel Institute of Technology, Haifa, Israel; Tel: +972.4.8292246; Fax: +972.4.8295697;

E-mail: avishap@technion.ac.il countries, to which workers are submitted at construction sites and which can also be felt by nearby residents and those passing by the construction site. Although several studies were conducted in developed countries such as the Netherlands, UK, and USA regarding the quantitative evaluation of exposure to dust generated in the course of some specific construction tasks and dust control measures [5-11], the authors found no similar published work concerning building construction sites in developing countries.

In Brazil, the prevalence of workers exposed to dust is higher than that observed in European countries such as the UK, Germany, France, Spain, and Finland [12]. Exposure to crystalline silica does not, in itself, explain the prevalence of silicosis, the common respiratory illness related to inhalation of mineral dust; factors such as concentration and exposure time count too. However, occupational exposure to silica is a sufficient motive for control and prevention through the study and adoption of control measures.

Ribeiro et al. [12,13] estimated the number of workers exposed to silica for various industries in Brazil. An occupational exposure matrix was constructed to relate activity and occupation to the average number of exposed workers in the years 1999-2001. Exposure time throughout the workweek was also studied. Beyond merely estimating silica exposure in workers in the formal labor market, the study also concluded that the risk of exposure may be much higher among workers in the informal labor market of the Brazilian economy. Results revealed that, of the industries studied, the highest rate of workers unquestionably exposed to silica dur- 
ing over $30 \%$ of the workweek may be found in the construction industry $(62 \%-65 \%$ in $1999-2001)$. These rates were higher than those found for traditional dust-generating industries such as mineral extraction and non-metal mining (ceramic, glass, cement).

Given this alarming data on silica exposure and considering the damaging effect of other types of dust that construction workers are exposed to $[14,15]$, the principal objective of the current study was to quantitatively assess the levels of total and respirable dust in activities performed at building construction sites in Brazil during the structural and finishing works, based on the results of previous qualitative studies on this subject [16-18]. Brazil is considered in this context to be representative of the emerging economies in the developing world, which include also Russia, India, and China (known together as BRIC).

\section{THEORETICAL REFERENCE}

\section{Basic Terms}

The World Health Organization (WHO) defines dust as "solid particles, ranging in size from $1 \mu \mathrm{m}$ to $100 \mu \mathrm{m}$, that may be or become dispersed in the air, depending on their origin, physical characteristics and environmental conditions" [19]. Thus, for the purpose of evaluating particulate matter suspended in the air at work sites, particle size is considered the primary factor for determining health risk. Another important factor is the determination of dust concentration that defines the body's tolerance limit.

The current study analyzed total, inhalable, and respirable dust generated by different types of dust produced at building construction sites. Additionally, dust was classified according to its composition: dust with silica, wood dust, and particulates not otherwise specified (PNOS) [20].

\section{National and International Exposure Limits for Dust}

With regard to Brazilian Occupational Safety and Hygiene legislation, the Regulatory Standards (known in Brazil as NR) can be cited as most important for the construction industry [21]. And among them, NR9 and NR15 are directly related to the development of the current study.

NR15 establishes the occupational exposure limits (OELs) that define, based on quantitative evaluations, the maximum or minimum concentration of agents present in the work environment that will not harm workers' health. When referring hereafter to the NR15 OELs, the term Tolerance Limit (TL) is used according to the terminology used in the Brazilian legislation. NR9 establishes the Environmental Hazard Prevention Program, whose principal objective is to ensure that companies present a methodology of action that guarantees the preservation of workers' health and well-being in face of the hazards of the work environment (i.e., physical, chemical, and biological agents whose damage potential depend on their nature, concentration, and exposure time). NR9 also defines the term Action Level (AL) as the value above which preventive action must be initiated to minimize the probability that exposure to the specific environmental agent will exceed the exposure limits. For chemical agents, the AL is $50 \%$ of the TL mentioned in NR15.
In Brazil, once the levels of total dust and respirable dust are identified and quantified, their concentrations must be compared with the TL to assess the severity of exposure. National limits may be adopted from NR15 and in the absence of national limits, and as prescribed by NR9, international exposure limits given by the American Conference of Governmental Industrial Hygienists (ACGIH) may be adopted or limits may be established through union or collective bargaining negotiation.

According to NR15, the TL for total dust and respirable dust containing free crystalline silica (quartz), for a workweek of up to 48 hours, are calculated by the following formulas (TL values in $\mathrm{mg} / \mathrm{m}^{3}$ ):

$$
\begin{aligned}
& \text { For respirable dust: } \mathrm{TL}_{\mathrm{RD}}=\frac{8}{\% \text { quartz }+2} \\
& \text { For total dust: } \mathrm{TL}_{\mathrm{TD}}=\frac{24}{\% \text { quartz }+3}
\end{aligned}
$$

For activities that involve exposure to dust that does not contain silica, OEL comparisons are made using only ACGIH guide values. According to the ACGIH, the occupational exposure limit TLV-TWA (Threshold Limit Value Time Weighted Average) and the guide values were established for a workweek of 40 hours. It is therefore necessary to adjust these values for the Brazilian workweek of 44 hours (or $h$ weekly hours in general). The adjusted values, displayed in Table 1, are calculated by multiplying the exposure limits given by the ACGIH by the reduction factor $(R F)$ of the Brief and Scala Model [22], according to Equation (3):

$$
R F=\frac{40}{h} \times \frac{168-h}{128}
$$

Referring to wood dust OELs, the Scientific Committee for Occupation Exposure Limits of the European Union stated that exposure to hard or soft wood dust $>0.5 \mathrm{mg} / \mathrm{m}^{3}$ induces pulmonary effects and should therefore be avoided. Nevertheless, in the UK, a much higher workplace exposure limit of $5 \mathrm{mg} / \mathrm{m}^{3}$ for 8-h OEL was established in 2005 [23]. The OEL used as reference in the present study $\left(1.0 \mathrm{mg} / \mathrm{m}^{3}\right.$, adjusted to $0.881 \mathrm{mg} / \mathrm{m}^{3}$, see Table 1), which was established by the ACGIH for all species of wood (except Western Red Cedar), falls between these two values.

\section{METHODS}

An earlier qualitative research project on the current subject [16-18] evaluated various parameters concerning exposure to dust through worksite visits, surveys, document analysis, and interviews conducted at 25 high-rise building construction sites in Recife, Brazil. The research considered 22 construction companies, including small, mediumsized, and large companies. Equipment, hand-tools, and construction materials used in the production process were identified. Also identified were nine principal dustgenerating activities performed by workers, of which sixthe most critical and frequent activities-were chosen for the quantitative analysis executed in the current study: (1) tile cutting; (2) mortar/concrete mixing; (3) worksite cleaning; (4) woodcutting; (5) plastering; and (6) wall/ceiling sanding for paintwork. 
Table 1. Adjusted occupational exposure limit values for 44hour workweek.

\begin{tabular}{|c|c|c|}
\hline Type of Dust & $\begin{array}{c}\text { TLV-TWA / Guide } \\
\text { value }^{\mathrm{c}} \\
\left(\mathrm{mg} / \mathrm{m}^{3}\right)\end{array}$ & $\begin{array}{c}\text { Adjusted TLV- } \\
\text { TWA } \\
\left(\mathrm{mg} / \mathrm{m}^{3}\right)\end{array}$ \\
\hline $\begin{array}{l}\text { Crystalline silica ( } \alpha- \\
\text { quartz and cristobalite) }\end{array}$ & Respirable dust $=0.025$ & Respirable dust $=0.022$ \\
\hline $\begin{array}{l}\text { PNOS }^{\mathrm{A}} \text { for dust from } \\
\text { plaster and spackling }\end{array}$ & $\begin{array}{l}\text { Respirable dust }=3 \\
\text { Inhalable dust }=10\end{array}$ & $\begin{array}{c}\text { Respirable dust }=2.643 \\
\text { Inhalable dust }=8.807\end{array}$ \\
\hline Wood dust ${ }^{B}$ & Inhalable dust $=1$ & Inhalable dust $=0.881$ \\
\hline
\end{tabular}

${ }^{\text {A } P N O S: ~ p a r t i c u l a t e s ~ n o t ~ o t h e r w i s e ~ s p e c i f i e d ~}$

${ }^{\mathrm{B}}$ TLV-TWA for all types of wood except Western Red Cedar

${ }^{\mathrm{C}}$ Source: ACGIH [20]

Through the study of both Brazilian and international legislation and official sampling methods, a sampling plan and collection strategy were established to evaluate and quantify total dust, inhalable dust, and respirable dust.

The sampling plan was designed in accordance with the collection and calculation method of the Brazilian occupational hygiene standard NHO 08 [24]. Samples were collected over fifteen days at four construction sites in the Recife metropolitan area, referred to as A, B, C, and D. In total, 45 cartridge samples and four controls were collected. The total number of concentrations analyzed was, however, only 24 since some samples were collected in a partial manner, using two cartridges for a single day. The main methods and materials of the study are described in what follows.

\section{Sampling Scheme}

Table 2 presents the scheme for the collection and analysis of the dust samples. The analytical methods used were those established by the Manual of Analytical Methods of the National Institute for Occupational Safety and Health (NIOSH) [25]. NIOSH 0500 method was used for the gravimetric analysis of total dust; NIOSH 0600 method was used for respirable dust; and NIOSH 7602 method was used for free crystalline silica in total and respirable portions (for the first three activities in Table 2 ).

\section{Materials, Equipment, and Instruments}

The following materials, equipment, and instruments were used to collect dust samples [as illustrated in Fig. (1)]:

- Sampling air pump - two GILAIR 5 units were used and verified by the soap-bubble method described in NHO 07 [26] at a flow rate of approximately $1.8 \mathrm{~L} / \mathrm{min}$. for total dust and $1.7 \mathrm{~L} / \mathrm{min}$. for respirable dust.

- Membrane filter - PVC 5 filters with 37-mm diameter and $5-\mu \mathrm{m}$ pore-diameter were used for samples containing silica, while PTFE 37 membrane filters (also with 5$\mu \mathrm{m}$ pore-diameter) were used for samples not expected to contain silica.

- Filter port - also known as a cartridge, which houses the membrane filter.

- Particle separator - a $10 \mathrm{~mm}$ nylon Dorr-Oliver cyclone was used to collect respirable dust particles. The cyclone is designed to separate the respirable fraction of airborne dust from the non-respirable fraction.

\section{Sample Collection and Analysis}

Individual (personal) samples were collected using the collection device [see Figs. (1-3)], which was placed in the breathing zone of the workers. Measurements were performed after workers were briefed on the experiment. Daily activities and relevant situations were documented in a preformatted manner throughout the collection.

The ideal collection time for a workday is 8 hours, but in practice this time varied, depending on the situation, between 6 and 8 hours (with the exception of the granite cutter, who was sampled throughout the time he actually performed the specified activity). Hence each sample was adjusted to a standard 8-hour workday.

Table 2. Scheme for collection and analysis of dust samples.

\begin{tabular}{|c|c|c|c|c|c|c|}
\hline \multirow{2}{*}{ Activity } & \multicolumn{2}{|c|}{ Total Dust Analysis (NIOSH 0500) } & \multicolumn{2}{|c|}{$\begin{array}{c}\text { Respirable Dust Analysis (NIOSH } \\
\text { 0600) }\end{array}$} & \multicolumn{2}{|c|}{$\begin{array}{c}\text { Respirable Silica Analysis (NIOSH } \\
\text { 7602) }\end{array}$} \\
\hline & No. of Samples & $\begin{array}{l}\text { Mean Duration } \\
\quad \text { (min.) }\end{array}$ & No. of Samples & $\begin{array}{l}\text { Mean Duration } \\
\quad(\text { min.) }\end{array}$ & No. of Samples & $\begin{array}{l}\text { Mean Duration } \\
\text { (min.) }\end{array}$ \\
\hline \multicolumn{7}{|c|}{ Samples containing free crystalline silica } \\
\hline Worksite cleaning & 1 & 401 & 2 & 409 & 3 & 406 \\
\hline \multicolumn{7}{|c|}{ Samples without free crystalline silica } \\
\hline Woodcutting & 3 & 378 & 2 & 385 & - & - \\
\hline
\end{tabular}




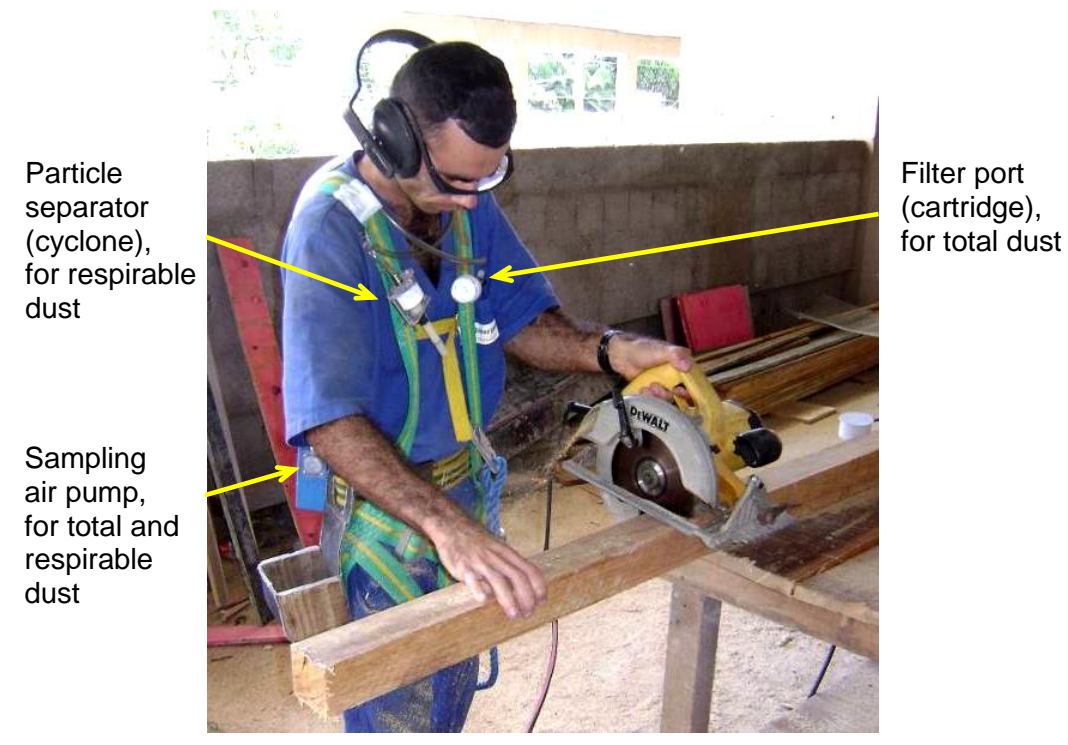

Fig. (1). Woodcutting.

Three types of collection were used, in terms of collection period and the number of samples. The first was a single sample over the entire period, collected continuously using a single cartridge, with a 1-hour intermission for lunch (during which time the sampling pump was turned off). This was used for all woodcutting and sanding for paintwork, as well as on some of the sites/days for mortar mixing and plastering; it is considered the preferred method for activities where neither was saturation due to great amounts of dust expected, nor were non-dust-producing tasks included in the activity. The second was consecutive samples over the entire period, collected using two cartridges, one for the morning and the other for the afternoon. This was done for all tile cutting and worksite cleaning, as well as on some of the sites/days for mortar mixing and plastering, to prevent cartridge saturation. Daily concentrations were calculated using the average weighted by the collection time for each cartridge. The third type involved consecutive samples for a partial period, collected only during the time the worker was actually engaged in the target activity; this was because, for certain periods of time, the overall activity - tile cutting - included also non-dustproducing tasks. In this case, two concentrations were calculated using a weighted average; however, in this case, results did not represent a typical workday. To make it possible to compare these values with the OELs, a best-case scenario was considered, whereby concentrations during the time not sampled were taken to be zero, as shown in Equation 4:

$$
C_{M P D}=\frac{C_{m} t_{t}+C_{s e} t_{s e}}{t_{d}}
$$

$C_{M P D}=$ daily weighted average concentration, $\mathrm{mg} / \mathrm{m}^{3}$

$C_{m}=$ average concentration of particulate matter obtained by partial sample, $\mathrm{mg} / \mathrm{m}^{3}$

$C_{s e}=$ particulate concentration in non-sampled period, taken to be zero

$t_{t}=$ total collection time of partial sample, min.

$t_{s e}=$ time without sampling, $t_{d}-t_{t}$, min.

$$
t_{d}=\text { total 8-hour workday, } 480 \mathrm{~min} \text {. }
$$

Although this calculation enables a comparison with the OELs, it must be remembered that this zero-assumption may not be the most advantageous for the worker. This issue is further elaborated in the next section (Results and Analysis).

\section{Laboratory Analysis}

Sample analysis was executed at a laboratory situated in São Paulo that was accredited by the American Industrial Hygiene Association (AIHA) as well as by the ACGIH.

The content of $\alpha$-quartz ( $\% \mathrm{SiO}_{2}$ ) found in respirable and total dust does not only allow the calculation of $\alpha$-quartz concentration but also the calculation of the TL in accordance with NR15. To establish the level of risk to workers' health, the concentrations were also compared with the international OELs (TLV-TWA) prescribed by the ACGIH (see Table 1).

Results of the analyses of wood dust and of plaster and spackling dust were given by the laboratory in terms of total inhalable dust concentration. Since NR15 does not define OELs for total and respirable dust from wood, the TLV given by the ACGIH was used for inhalable and respirable dust (see Table 1). Since no OELs are defined for plaster or spackling dust by NR15 or by the ACGIH, the concentrations found were compared with the guide values recommended by the ACGIH for insoluble or low-solubility PNOS, as plaster and spackling meet the requirements of ACGIH [20].

\section{RESULTS AND ANALYSIS}

The results of this study represent the situation during the evaluation period of particulate matter suspended in the air for each of the analyzed activities. It is noted that dust concentration can vary over the course of a workday or a workweek depending on the methods, raw materials, equipment and tools used, on environmental conditions, and on the workforce's skill level. 
The results are summarized in Tables $\mathbf{3}$ and 4, which present the mean and standard deviation of the collected concentrations, as well as a comparison with the OELs defined by NR15 and/or the ACGIH.

\section{Respirable and Total Dust Containing Free Crystalline Silica}

Table 3 summarizes the results of the dust samples potentially containing free crystalline silica generated during tile cutting, mortar/concrete mixing, and worksite cleaning. Data analysis included not only mean values (as presented in Table 3) but also the specificities of the measurement of each individual worksite/day. A detailed explanation of the analysis and results obtained for each activity are presented below.

\section{Tile Cutting}

Among the activities sampled for dust potentially containing silica, tile cutting with an electric circular saw was the one with the most critical results in terms of occupational exposure. The mean total dust reached $100 \%$ of the NR15 tolerance level as presented in Table 3, which represents the weighted average for an 8-hour workday. It is important to note that total dust and respirable dust samples were collected only during the actual time the tile cutter performed the cutting activity. At one of the two examined sites, for instance, sampling time was 3 hours and $35 \mathrm{~min}$. and total dust concentration was $3.458 \mathrm{mg} / \mathrm{m}^{3}$ with $0.512 \mathrm{mg} / \mathrm{m}^{3}$ of crystalline silica, or $266 \%$ of the tolerance level established by NR15. After calculating the weighted average for an 8hour workday using Equation 4, the total dust concentration decreased to $1.549 \mathrm{mg} / \mathrm{m}^{3}$ with $0.229 \mathrm{mg} / \mathrm{m}^{3}$ of free crystalline silica, which equals $115 \%$ of the NR15 tolerance limit. Although the cutting activity in itself is generally of relatively short duration, the health effects of silica are known to be long term, being both cumulative and potentially chronic. Similarly, the concentration of respirable dust sampled at that site was $0.409 \mathrm{mg} / \mathrm{m}^{3}$ with $0.09 \mathrm{mg} / \mathrm{m}^{3}$ of crystalline silica, or $120 \%$ of the NR15 tolerance limit and $400 \%$ of the ACGIH-defined limit. However, since this sample represented only 3 hours and $35 \mathrm{~min}$. of work and assuming zero dust exposure for the rest of the full 8-hour day, the adjusted concentration of respirable dust dropped to $0.183 \mathrm{mg} / \mathrm{m}^{3}$ with $0.04 \mathrm{mg} / \mathrm{m}^{3}$ of crystalline silica, or $55 \%$ of the NR15 limit (slightly above the AL) and $182 \%$ of the ACGIH limit (well above the TLV-TWA).

\section{Mortar/Concrete Mixing}

Dust generated by mortar/concrete mixing was visible mainly when unbagging the cement, sifting sand, mixing lime and sand, as well as during the supply and operation of the mixer. The results were lower than the action level established by regulations for both the total and respirable fractions (about $40 \%$ for total dust and $25 \%$ for respirable dust compared with NR15 limits, as shown in Table 3). Worksite A, at which concentrations were higher among the two sites examined, yielded a mean total dust value of $3.732 \mathrm{mg} / \mathrm{m}^{3}$, or $50 \%$ of the NR15 tolerance limit, and a mean respirable dust value of $0.404 \mathrm{mg} / \mathrm{m}^{3}$, or $26 \%$ of the NR15 limit and $57 \%$ of the TLV-TWA.

\section{Worksite Cleaning}

Worksite cleaning presented even lower concentrations of total and respirable dust than did mortar/concrete mixing (see Table 3). Data related to this activity were collected from sites A and D. At worksite A, where the person responsible for cleaning was also engaged in several miscellaneous activities, results for total and respirable dust represented about $17 \%$ of the NR15 TL. At worksite D, the cleaner performed ceramic floor sweeping throughout the entire data collection time. In this case, dust was visible during the entire sweeping activity and respirable dust concentration was $0.577 \mathrm{mg} / \mathrm{m}^{3}$, which represents $33 \%$ of the NR15 TL. Data collection at site D was performed consecutively for a full period using two cartridges, one for the morning and one for the afternoon. Final concentrations were determined using a weighted average. It is suggested that, for this activity, collection be performed in the future using a single cartridge for the entire workday.

\section{Respirable and Total Inhalable Dust without Free Crys- talline Silica}

Table 4 summarizes the results of dust samples without free crystalline silica generated during woodcutting, plastering, and sanding prior to paintwork. A detailed explanation of the analysis and results obtained for each activity are presented below.

Table 3. Total dust and respirable dust with the presence of silica.

\begin{tabular}{|c|c|c|c|c|c|c|c|c|c|c|c|}
\hline \multirow{3}{*}{ Activity } & \multicolumn{5}{|c|}{ Total Dust } & \multicolumn{6}{|c|}{ Respirable Dust } \\
\hline & \multicolumn{2}{|c|}{$\begin{array}{c}\text { Total Dust } \\
\text { Concentration } \\
\left(\mathbf{m g} / \mathbf{m}^{3}\right)\end{array}$} & \multicolumn{2}{|c|}{$\begin{array}{c}\text { Silica } \\
\text { Concentration } \\
\left(\mathrm{mg} / \mathrm{m}^{3}\right)\end{array}$} & \multirow{2}{*}{$\begin{array}{c}\% \\
\begin{array}{c}\text { Concentration } \\
\text { Relative to: }\end{array} \\
\text { TL NR15 }\end{array}$} & \multicolumn{2}{|c|}{$\begin{array}{c}\text { Respirable Dust } \\
\text { Concentration } \\
\left(\mathrm{mg} / \mathrm{m}^{3}\right)\end{array}$} & \multicolumn{2}{|c|}{$\begin{array}{c}\text { Silica } \\
\text { Concentration } \\
\left(\mathbf{m g} / \mathbf{m}^{3}\right)\end{array}$} & \multicolumn{2}{|c|}{$\begin{array}{l}\% \text { Concentration } \\
\text { Relative to: }\end{array}$} \\
\hline & Mean & $\begin{array}{l}\text { Std. } \\
\text { dev. }\end{array}$ & Mean & Std. dev & & Mean & $\begin{array}{l}\text { Std. } \\
\text { dev. }\end{array}$ & Mean & $\begin{array}{l}\text { Std. } \\
\text { dev }\end{array}$ & $\begin{array}{c}\text { TL } \\
\text { NR15 }\end{array}$ & $\begin{array}{l}\text { TLV- } \\
\text { TWA }\end{array}$ \\
\hline Tile cutting & 2.275 & 1.026 & 0.173 & 0.079 & 100.5 & 0.183 & - & 0.040 & - & 54.6 & 181.8 \\
\hline $\begin{array}{l}\text { Mortar/concrete } \\
\text { mixing }\end{array}$ & 2.696 & 1.466 & 0.013 & 0.006 & 38.9 & 0.537 & 0.119 & 0.010 & 0.003 & 25.3 & 43.2 \\
\hline Worksite cleaning & 1.217 & - & 0.007 & - & 18.1 & 0.427 & 0.213 & 0.011 & 0.004 & 24.4 & 50.0 \\
\hline
\end{tabular}


Table 4. Total dust and respirable dust without the presence of silica.

\begin{tabular}{|c|c|c|c|c|c|c|}
\hline \multirow{3}{*}{ Activity } & \multicolumn{3}{|c|}{ Total Dust } & \multicolumn{3}{|c|}{ Respirable Dust } \\
\hline & \multicolumn{2}{|c|}{ Total Dust Concentration $\left(\mathrm{mg} / \mathrm{m}^{3}\right)$} & \multirow{2}{*}{$\begin{array}{c}\begin{array}{c}\text { \% Concentration } \\
\text { Relative to: }\end{array} \\
\text { TLV ACGIH }\end{array}$} & \multicolumn{2}{|c|}{ Respirable Dust Concentration $\left(\mathrm{mg} / \mathrm{m}^{3}\right)$} & \multirow{2}{*}{$\begin{array}{c}\% \text { Concentration } \\
\text { Relative to: }\end{array}$} \\
\hline & Mean & Std. dev. & & Mean & Std. dev. & \\
\hline Woodcutting & 1.397 & 0.585 & 158.6 & 0.202 & 0.129 & - \\
\hline Paintwork & 32.458 & 22.857 & 368.4 & 1.294 & 0.066 & 49.0 \\
\hline
\end{tabular}

\section{Woodcutting}

Wood dust was visible only when an electric circular saw was used for cutting [see Fig. (1)]. This activity presented dust levels higher than the ACGIH TLV of $1 \mathrm{mg} / \mathrm{m}^{3}(159 \%$ of the adjusted $0.881 \mathrm{mg} / \mathrm{m}^{3}$ value; see National and International Exposure Limits for Dust above and Table 1). Although the ACGIH provides no exposure limits for respirable wood dust, a weighted average concentration of $0.202 \mathrm{mg} / \mathrm{m}^{3}$ was detected over two days, which means that wood dust does exist in the respirable fraction of the samples analyzed.

\section{Plastering}

No quantitative evidence of exposure to plaster dust above the reference OEL (i.e., ACGIH TLV for PNOS; see Laboratory Analysis above) was found for the plaster preparation and application activity, even though suspended particles were visibly present [see Fig. (2)]. The results show that the mean concentration of four whole-day samples collected at worksite B was below both the OEL and even the AL.

Note that, although the worker shown in Fig. (2) was using a protective mask, the effect of the mask was not taken into consideration when evaluating the worker's exposure to dust (as the intent of the study was to identify what activities at the site produced dust levels above the OEL).

\section{Preparation for Paintwork}

The generation of dust during the sanding of spacklingcovered surfaces was considered to be the most aggressive in terms of visual perception. Dust was visible during the entire activity, which was performed manually with sandpaper (and without gloves). The worker sought to protect himself by using respiratory protective equipment and protective goggles; a T-shirt wrapped around the head was used in an attempt to reduce the penetration of dust into the eyes and airways [see Fig. (3); note the presence of dust on the camera lens itself).

The mean concentration of total spackling dust, over 32 $\mathrm{mg} / \mathrm{m}^{3}$, was $368 \%$ of the value recommended by the ACGIH. Dust exposure due to sanding of spackling was also evident in the respirable fraction of the samples. Although spackling dust is not considered fibrogenic, it can still cause problems such as allergies, asthma, and other pneumoconiosis due to high concentration and systemic exposure.
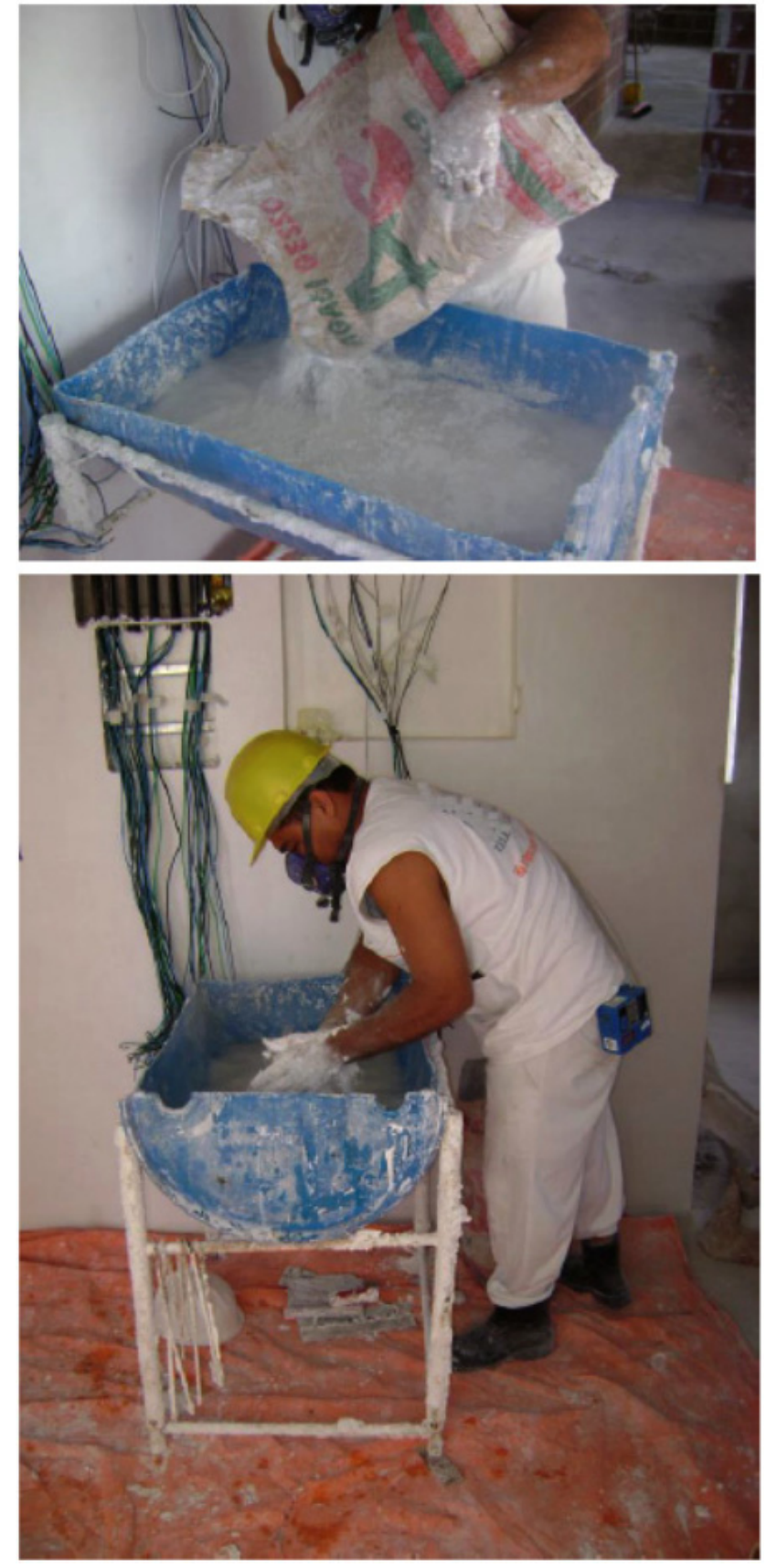

Fig. (2). Preparation of plaster (top: unbagging the plaster powder; bottom: preparing the plaster paste). 


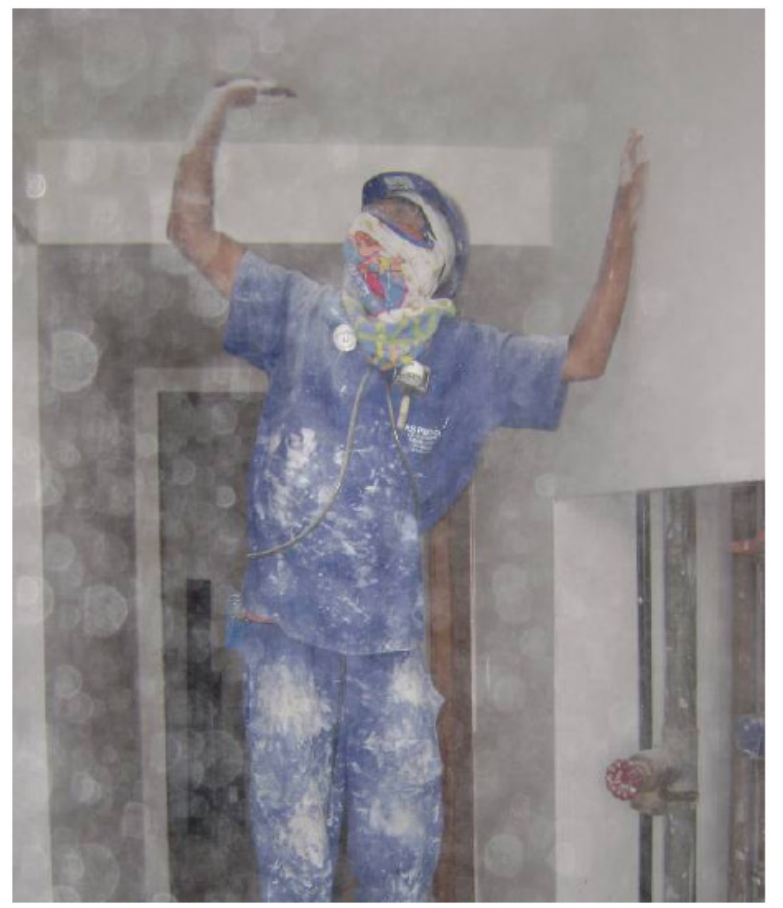

Fig. (3). Sanding the ceiling for paintwork.

\section{CONCLUSIONS}

Laboratory analyses revealed that the most critical jobs in terms of dust exposure are tile cutting (which includes granite, ceramic, and porcelainites), woodcutting with a circular saw, and sanding of walls and ceilings prior to paintwork. Other, less critical activities that must still be considered in the context of the prevention of lung diseases are mortar/concrete mixing, worksite cleaning, and plastering.

The results of this study affirm the need to adopt a respiratory protection program for building sites during both the structural works and the finishing works phases. Major findings may be summarized as follows:

- The woodcutting activity, performed by the carpenter mostly during the formwork phase, produced a mean concentration of total inhalable dust that exceeded the OEL value defined by the ACGIH. Concentrations of respirable dust were also determined, but neither NR15 nor the ACGIH have defined exposure reference values for respirable wood dust. It is therefore deemed important to further study this fraction to determine if and what OELs are appropriate in this case.

- The tile cutting activity, performed in the course of laying floors, was the activity that exhibited the highest concentrations of crystalline silica in the $\alpha$-quartz form. Not only did the mean concentrations exceed the OELs, but they were particularly high during the actual tile cutting activity carried out with an electric circular saw with a dry blade. Although this activity is performed only intermittently during the workday, the values observed are considered high risk in terms of exposure to crystalline silica. It may therefore be helpful to determine short-term exposure limit values for crystalline silica, like those that exist for other types of dusts. Evidence of processes that produce peak concentrations within a short time period, even when values adjusted for an 8-hour day are below the OELs, is important for the adoption of effective preventive control measures.

- Plastering caused low concentrations of dust, even when compared to the AL. Given the considerably visible plaster dust this operation produced [see Fig. (2)], this finding was quite surprising. It was noted that the plasterer used respiratory protective equipment during the entire plaster preparation activity; in this case, the use of protective gloves during the activity is also recommended.

- Dust concentrations caused by the sanding of spackling during paintwork exceeded the OEL for total dust and practically equaled the AL for respirable dust. Control measures, such as the use of appropriate respiratory protective equipment, should be taken to prevent respiratory tract illnesses; use of other types of personal protection equipment is recommended (e.g., protective goggles, hat with neck flap, gloves, and a long-sleeved shirt).

- Mortar/concrete mixing activities, while performed in an environment with visible dust, did not produce dust concentrations above the OELs. This activity involves a lot of movement manipulating materials that produce dust with and without silica. However, only one sample proved the presence of free crystalline silica, and even in this case the concentration of total dust was below the AL. It is therefore evident that this activity does not present a conclusive risk of exposure to free crystalline silica. Nevertheless, preventive control measures should not be neglected given the presence of this chemical agent when this activity is performed.

In light of the results and evidence presented here, which may be regarded as representing the practices in other emerging economies, there is a clear need to adopt collective and individual control measures to cope with dust exposure at building construction sites in developing countries. Such measures include humidification when sweeping and cutting tiles, spatial isolation of dust-generating equipment, temporal isolation of dust-generating activities, use of appropriate respiratory protective equipment, and awareness training about the risks associated with exposure to dust. These measures should be followed by systematic monitoring and periodic evaluation of the efficiency of the measures adopted, as well as by the updating of indexes and methods used in national legislation regarding OELs established for different types of dust.

\section{CONFLICT OF INTEREST}

The authors confirm that this article content has no conflicts of interest.

\section{ACKNOWLEDGEMENTS}

This paper was completed as part of the first author's post-doctoral work, which was funded by CAPES Process No. 0770-11-6 and the University of Pernambuco. The hospitality of the Faculty of Civil and Environmental Engineering at the Technion-Israel Institute of Technology and of University of Minho, Portugal, is gratefully acknowledged. The authors also thank the staff of the Occupational Safety and Health Laboratory of the Polytechnic School of Pernam- 
buco, and particularly Prof. Eliane M. G. Lago and Eng. W. A. F. Alencar, for their assistance with the field work and data analysis.

\section{REFERENCES}

[1] Ministry of Social Security. Statistical yearbook of social security 2010. Brasília, Brazil, 2011. Available at http://www.mpas.gov.br/arquivos/office/3_111202-105619-646.pdf (accessed 11 August 2013).

[2] Hammer W. Occupational safety management and engineering. Englewood Cliffs, NJ: Prentice-Hall 1989.

[3] McDonald N, Hrymak V. Safety behavior in the construction sector. Dublin, Ireland: Occupational Safety and Health Institute of Ireland 2002.

[4] Shapira A, Simcha M, Goldenberg M. Integrative model for quantitative evaluation of safety on construction sites with tower cranes. J Constr Eng Manage 2012; 138(11): 1281-93.

[5] Akbar-Khanzadeh F, Brillhart RL. Respirable crystalline silica dust exposure during concrete finishing (grinding) using hand-held grinders in the construction industry. Ann Occup Hyg 2002; 46(3): 341-6.

[6] Lumens MEGL, Spee T. Determinants of exposure to respirable quartz dust in the construction industry. Ann Occup Hyg 2001; 45(7): 585-95.

[7] Peters S, Thomassen Y, Fechter-Rink E, Kromhout H. Personal exposure to inhalable cement dust among construction workers. J Environ Monit 2009; 11(1): 174-80.

[8] Rappaport SM, Goldberg M, Susi P, Herrick RF. Excessive Exposure to Silica in the US Construction Industry. Ann Occup Hyg 2003; 47(2): 111-22.

[9] Spee T, van de Rijdt E, van Hoof W, Noy D, Kromhout H. Exposure to wood dust among carpenters in the construction industry in The Netherlands. Ann Occup Hyg 2007; 51(3): 241-8.

[10] Thorpe A, Ritchie AS, Gibson MJ, Brown RC. Measurements of the effectiveness of dust control on cut-off saws used in the construction industry. Ann Occup Hyg 1999; 43(7): 443-56.

[11] Tjoe Nij E, Hilhorst S, Spee T, et al. Dust control measures in the construction industry. Ann Occup Hyg 2003; 47(3): 211-8.

[12] Ribeiro FSN, Camargo EA, Algranti E, Wunsch FilhoV. Occupational exposure to sílica in Brazil in 2001. Revista Brasileira de Epidemiologia [Brazilian Epidemiology Journal] 2008; 11(1): 8996 (in Portuguese).

[13] Ribeiro FSN, Algranti E, Camargo EA, Wunsch Filho V. Design and validation of a job-exposure matrix to silica. Revista Saúde Pública [Public Health Journal] 2005; 39(1): 18-26 (in Portuguese).

[14] Bergdahl IA, Torén K, Eriksson K, et al. Increased mortality in COPD among construction workers exposed to inorganic dust. Euro Resp J 2004; 23(3): 402-6.
[15] Tjoe Nij E, Heederik D. Risk assessment of silicosis and lung cancer among construction workers exposed to respirable quartz. Scand J Work Environ Health 2005; 31(2): 49-56.

[16] Barkokébas Junior B, Kohlman Rabbani ER, Lago EMG, Vasconcelos B, Martins ARB, Alencar WAF. Characterization of airborne dust in building construction sites. Proceedings of the International Symposium on Occupational Safety and Hygiene (SHO), Guimarães, Portugal 2010.

[17] Kohlman Rabbani ER, Barkokébas Junior B, Lago EMG, Martins ARB, Alencar WAF. Study of dust present at building sites and its effect on workers' safety and health. Proceedings of the XVI International Conference on Industrial Engineering and Operations Management (ICIEOM) 2010, Rio de Janeiro, Brazil. Available at http://www.abepro.org.br/biblioteca/enegep2010_TI_ST_116_761_ 15193.pdf (accessed 11 August 2013).

[18] Martins ARB. Characterization and evaluation of dust present at construction building sites. MSc [thesis]. Recife, Brazil: Polytechnic School of University of Pernambuco; 2009.

[19] World Health Organization (WHO). Hazard prevention and control in the work environment: airborne dust. In Protection of the human environment occupational and environmental health series. Geneva: WHO/SDE/OEH/99.14, 1999.

[20] American Conference of Governmental Industrial Hygienists (ACGIH). Threshold limit values and biological exposure indices. Cincinnati, Oh: ACGIH, 2008.

[21] Ministry of Labor. Ordinance (Portaria) No. 3214 (1978). Brasília, Brazil, 1978. Available at http://portal.mte.gov.br/legislacao/ portaria-n-3-214-de-08-06-1978-1.htm (accessed 11 August 2013).

[22] Gruenzner G. Evaluation of silica dust: a case study in a quarry in São Paulo. MSc [thesis]. São Paulo, Brazil: Polytechnic School of University of São Paulo; 2003.

[23] Galea K, Van Tongeren M, Sleeuwenhoek MJ, et al. Trends in wood dust inhalation exposure in the UK 1985-2005. Ann Occup Hyg 2009; 53(7): 657-67.

[24] Foundation of Occupational Safety and Health. Occupational hygiene standard (NHO) 08: Collection of solid particulate matter suspended in the air at work environment. São Paulo, Brazil: FUNDACENTRO, 2009.

[25] National Institute for Occupational Safety and Health (NIOSH) Manual of analytical methods. Cincinnati, Oh.: Public Health Service Centers for Disease Control, 1994. Available at http://www.cdc.gov/niosh/nmam/method-2000-8000.html (accessed 11 August 2013).

[26] Foundation of Occupational Safety and Health. Occupational hygiene standard (NHO) 07: Pump calibration procedure for personal sampling using the soap bubble method. São Paulo, Brazil: FUNDACENTRO, 2002.

Received: November 13, 2013

Revised: January 04, 2014

Accepted: January 08, 2014

(C) Kohlman-Rabbani et al.; Licensee Bentham Open.

This is an open access article licensed under the terms of the Creative Commons Attribution Non-Commercial License (http://creativecommons.org/licenses/by-nc/3.0/) which permits unrestricted, non-commercial use, distribution and reproduction in any medium, provided the work is properly cited. 